\title{
Reading as Dialogical Document Work: Possibilities for Library and Information Science
}

\author{
Anna Hampson Lundh \\ Swedish School of Library and Information Science/Linnaeus Centre for Research on \\ Learning, Interaction and Mediated Communication in Contemporary Society, University of \\ Borås \\ Department of Information Studies, Curtin University, Western Australia
}

\section{Mats Dolatkhah}

Swedish School of Library and Information Science, University of Borås

\begin{abstract}
Purpose: This article introduces a dialogically based theory of documentary practices and document work as a promising framework for studying activities that are often conceptualised as Information Behaviour or Information Practices within Library and Information Science (LIS).

Design/methodology/approach: An empirical example - a lesson on how to read railway timetables - is presented. The lesson stems from a research project including 223 Swedish lessons recorded in Swedish primary schools 1967-1969. It is argued that this lesson, as many empirical situations within LIS research, can fruitfully be regarded as documentary practices which include document work such as reading, rather than instances of information behaviour.
\end{abstract}

Findings: It is found that the theoretical perspective of dialogism could contribute to the theory development within LIS, and function as a bridge between different subfields such as reading studies and documentary practices.

Research limitations/implications: The framework is yet to be applied on a larger scale. This would require a willingness to go beyond the entrenched idea of information as the core theoretical concept and empirical object of study within LIS.

Social implications: The theoretical framework offers a view of the relations between individuals, documents, and social contexts, through which it is possible to explore the social significance of core LIS concerns such as reading, literacy, and document work.

Originality/value: The theoretical framework offers an alternative to the monologist, information-based theories and models of people's behaviours and practices prevalent in LIS.

Keywords: Dialogism; Document Theory; Document Work; Information Behaviour; Information Practices; Literacy; Reading

Article classification: Conceptual paper 
Please cite the published version of the article

\section{Learning to Read Timetables}

In the inset in picture 1, a teacher is seen showing a document to her class. The picture is from the beginning of a lesson in the subject of Swedish in a Swedish primary school, in a Year 6 class where most pupils are 12 years old, in the afternoon of $3^{\text {rd }}$ March, $1968^{1}$. The document the teacher is presenting is an outdated version of a collection of timetables which can be translated to Communications in Sweden [Sveriges kommunikationer].

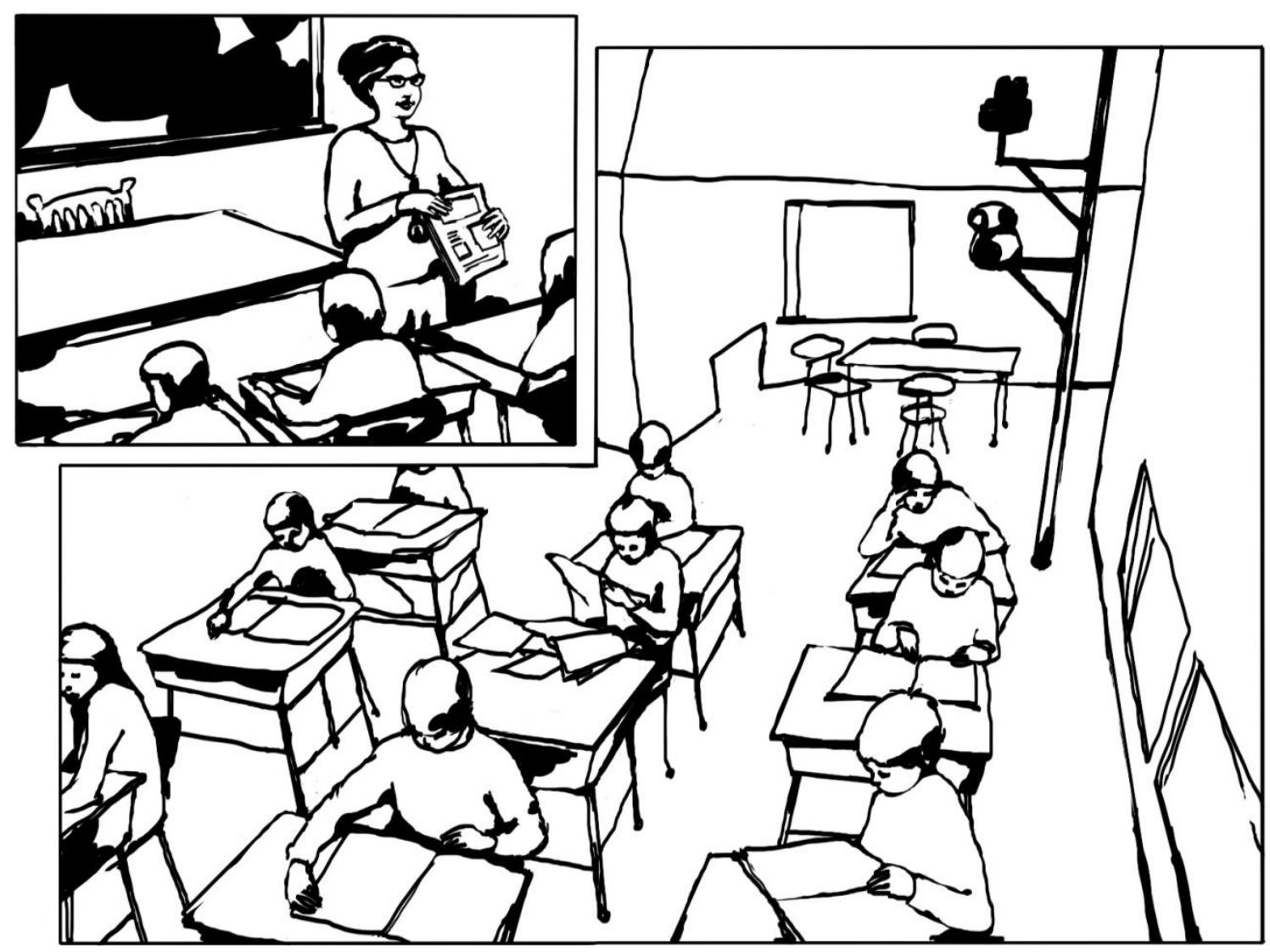

Picture 1. A snapshot from a video recording of a Swedish lesson on 3rd March, 1968. The inset shows the view from the camera at the back of the classroom, which can be seen in the right hand upper corner of the main picture. The image is re-drawn in order to ensure confidentiality.

The lesson from which Picture 1 is taken is focused on a particular kind of reading, namely the reading of railway timetables. The lesson can be summarised as follows: After the teacher has introduced Communications in Sweden she asks one of the pupils to read aloud from another document - a textbook for the subject of Swedish - which includes a section on how to read train timetables. When the pupil has finished the reading-aloud sequence, the teacher states that "if you don't know how to use one of these [timetables], it is certainly not easy to find your way in it". She then goes on to instruct the pupils in finding the timetable relevant to the town where they live, and continues to say that "... you need to know quite a lot to be able to cope. You have to understand the signs, what they mean". She explains some of the symbols used in the timetable and where to find the legend in Communications in Sweden. Then the pupils are instructed to move back to the textbook, in which another single timetable can be found together with some questions which the class 
responds to collectively. Examples of questions asked include departure and arrival times and distances between locations. Towards the end of the lesson, the pupils are asked to construct their own questions which their classmates are supposed to be able to answer with the help of the timetable in the textbook. At the very end of the lesson, the pupils are assigned homework relating to the textbook timetable. During the whole lesson, the teacher engages in classroom management practices, such as reprimanding pupils for being late and for interrupting their classmates.

For researchers in Library and Information Science (LIS), especially those interested in what people do with information resources, this lesson includes a range of potentially interesting activities. The use of a railway timetable - and the teaching and learning of this use - could be seen as a type of information behaviour that the pupils and the teacher engage in to solve one or several problems. However, it has been suggested (Frohmann, 2004a; 2004b; Hartel, 2010; McKenzie and Davies, 2010; Trace, 2007) that situations which are often conceptualised as Information Behaviour or Information Practices within LIS, could fruitfully be regarded as documentary practices and as including document work. In the following sections, we will build upon these ideas and explore dialogism as one useful theoretical foundation for LIS. Then we discuss how a dialogically based theory of documentary practices and document work could be employed in analyses of situations such as the railway timetable lesson.

\section{Monologism and Dialogism in the Study of People in LIS}

Dialogism is presented by the linguist and language theorist Linell (2009) as an alternative to dominant monologist theories in which the individual mind is seen as the basis for analyses and understandings of human action, activities, and practices. Linell (2009) critiques communication models where individual thought is taken as a starting-point and where communication problems are attributed to the "packaging" of thoughts - or of pieces of information - into messages and the subsequent decoding of this information.

In contrast to such individual-centric models, the dialogist approach begins in the interdependence between individual persons, events, artefacts and broader contexts. A key idea is that language, in a wide sense, is the foundation for this interdependence. It is through language that people think and act, and it is through language that larger societal discourses and individual minds are inextricably linked (Linell, 2009, p. 136). Language should here be understood as semiotic means that are put into and are doing work in human interaction. Hence, language is not seen as a static system in which signs have inherent meanings. Rather, it is in languaging, that is, "linguistic actions and activities in actual communication and thinking" (Linell, 2009, p. 274), that semiotic signs are created, maintained, and negotiated.

Dialogism is presented as a "counter-theory" to monologist theories (Linell, 2009, p. 35). As such, we believe it offers interesting possibilities for LIS studies on people's activities and practices around, through and with documents. Within LIS, a research strand with certain dialogist characteristics can be found in parts of document theory. Despite its name, document theory is not a unified theory, but rather an approach within LIS where the document is seen as a central concept and empirical object. The dialogical aspects of document theory are more evident in studies of documentary practices (Frohmann, 2004a; 
2004b) and document work (Hartel, 2010; McKenzie and Davies, 2010; Trace, 2007), than in work that has been done regarding the ontological question of what a document is (see Buckland, 1997; Frohmann, 2009; Lund, 2010). The basic idea that opens for dialogist thinking within documentary practices research is the view that documents "become informative" only through human practices, and that human practices are tied into social contexts and structures such as regimes of discipline and institutions (Frohmann, 2004b). The informativeness of a document depends on the interaction between people and documents, which is dialogical in character. The relationship between human action and social context is also dialogical in the sense of being mutually constitutive.

Even if it is not explicitly articulated as such, some features of dialogic theorising are also evident in LIS research on reading. The vocabulary is a bit different in this field: instead of talking about how documents become informative through practices, it is typically phrased as the meaning of texts which is constructed through active interpretation (Ross, 1999; Rothbauer, 2004). Similar ideas support much of the work undertaken in the related and partly overlapping field of the history of reading (Chartier, 2006; Pawley, 2002; Pawley, 2006). Even if the empirical contexts often differ between reading and document studies in LIS, the basic theoretical idea is quite similar as the emphasis and analytical starting point is the (dialogic) interaction between reader, artefact and the created experience of meaning or informativity.

Interest in documentary practices and document work within LIS can be seen as a reaction against monologistic models of information processing and information transfer that have underpinned a great deal of LIS theorising for several decades (Lund and Skare, 2009, pp. 1636f). Frohmann (2004a; 2004b), one of the main proponents of a materialistic document theory, argues that the preoccupation within LIS to define information as a theoretical concept, as well as some kind of an empirical substance, has led the discipline into a blind alley. Despite a large number of studies focussing on information behaviour, one of the seemingly ever-present questions in this field of research is what information actually is (e.g. Case, 2012, pp. 45-76). Commonly, information, that which is needed, sought, used, and shared is portrayed as a kind of immaterial "mental substance" (Frohmann, 2004b, pp. 389f) which not only is complicated or perhaps even impossible to study empirically, but also conceals issues relating to the situatedness of human activities and practices.

In our view, the elevation within LIS of the modern idea of information has meant that the LIS study of human behaviour and practices has become monologist, even when influenced by, for example, discursive theories or practice theories. Regardless of how information is defined, for example as some sort of invisible mental phenomenon, as oral utterances and conversation, and/or as something which exists in documents, in many cases (explicitly or implicitly) the concept tends to be associated with ideas of monologist signal-transmission in modern telecommunication (see e.g. Bates, 2010; Case, 2012, pp. 52-56). The problem, as we see it, is that what is essentially a theoretical perspective on certain categories of human communicative projects has been equated with a core object of study within LIS. Information, it seems, has become an all-encompassing concept, used for theorising, for guiding the design of empirical studies, as well as for promoting the LIS discipline as such (hence the movement to call the discipline Information Science/Studies only). The use of the concept of information, then, has a political undertone, suggesting an understanding of 
information as essential to the survival of the discipline, not least as it has been coupled with studies of high status social enterprises such as business, management and science.

We agree that the idea of "Information studies without information" (see Furner, 2004) or at least a discipline with "'information'-free Fridays" (Buckland, 2013, p. 51) is a possibility. In his puncture of the concept of information, Frohmann proposes a "shift from theories of information to descriptions of documentary practices" (2004a, p. 16, emphasis in original). In the following sections, we present a theoretical framework which should be seen as an attempt to exemplify how such a shift can be enacted. Our proposition is that situations such as the railway timetable lesson could benefit from being studied as dialogical activities and practices with words and documents, rather than instances of, for example, information behaviour. In particular, we elaborate on the concept of reading as a type of document work and an aspect of documentary practices, just as, for example information needs, information seeking, information use, and information sharing can be seen as aspects of information behaviour and information practices. The relevance of a dialogical theory of document work is however not limited to reading but could well be employed for studies of scholarly communication, social media, professional practices and other mainstream LIS concerns. Exploring the dialogicity of documentary practices and document work is intended to contribute to the theory development of this emerging research strand.

\section{Dialogical Document Work and Documentary Practices}

This framework, which draws on dialogism and document theory, entails a view of reading as a meaning-making activity, situated in specific situations, as well as part of wider historical traditions. Because of the situated character of reading, the study of reading activities and practices does not involve generalised models or lead to predictions of situations to come. Rather, it will provide accounts, illustrations and analyses of (historical) reading activities and traditions. In the following sections, some interrelated theoretical points of entry into reading as a unit of analysis will be presented, using the railway timetable lesson as an example.

\subsection{Reading Activities and Reading Traditions}

When arguing for the study of documentary practices rather than that of information behaviour, Frohmann (2004a, p. 15) proposes, by referring to the Wittgensteinian concept of language games that "[i]f we wish to know how one operates with words, we should look closely at the language games actually played. The important thing is what one does with the word, not something going on in the mind". Even a limited and mundane situation as the train timetable lesson offers ample opportunities to analyse how "one operates with words" in social situations, from the level of societal discourses and how they operate in classroom situations to the very close, situated level where people are interacting with, around, and through documents. For this interactional level, Trace (2007) has introduced the concept of document work.

When conceptualising reading as an empirical object of study, as an aspect of document work and documentary practices, the idea of "double dialogicity" (Linell 2009, pp. 51-53) is useful. It refers to the reciprocity between the analytical levels of a) situational negotiations and activities and b) socio-historical traditions. In the first sense, reading is a dialogical act between a reader, semiotic resources, and other actors in a specific situation. In the second 
sense, the particular situation is also involved in a dialogic interplay with wider societal and historical conditions which Linell describes as "situation-transcending practices" (2009, p. 52). These practices make up historical traditions that both shape and are shaped by particular situations. In relation to reading, we use the concept of reading activity to describe reading-related, situated document work, and reading traditions to describe reading-related, situation-transcending documentary practices.

The perspective of double dialogicity is useful in order to conceptualise the historicity (see Frohmann, 2004b) of reading activities, how they become manifest as situated document work and change over time as sociocultural traditions. When Frohmann emphasises the historical situatedness of documentary practices by highlighting that "[a]ttention to practices with documents reveals how it is that particular documents, at particular times and places and in particular areas of the social and cultural terrain, become informative" (2004b, p. 405), he actually highlights a double situatedness. Document work is never universal as it is produced and is taking place in a particular time and place. But at the same time, it is never isolated, as it is socially and culturally situated.

The idea of double dialogicity can be exemplified by the train timetable lesson. First, any reading activity is performed in a social situation which is localised in time and space. The timetable lesson has some marked features, such as the classroom, its furnishings, and the people participating in it. The activity of reading is tied into these features. The interaction between these children, this teacher, and these documents produced a local context that was specific for this time and place in history. Even though the recording from the lesson can be played over and over again, this actual situation will never be replicated. The lesson also illustrates well how reading is a social and interactional activity. For example, the pupil reading aloud in the beginning of the lesson does so when prompted by the teacher; his reading has, among other things, the function of letting the whole class take part of the text; and at the end of the reading the teacher takes over and elaborates on the topic of the text in an apparently seamless way. The reading activity is accomplished in situated dialogic interaction; it is not an individual act that is performed by the pupil in isolation. Even a reading activity that is taking place in solitude - for example, if one of the pupils from the reading lesson went home and did their homework alone - can be regarded as an interactional activity. The pupil interacts with the text brought home, with aspects of the self and the context of the home, as well as the frame of assumptions and expectations tied to the practice of homework - which leads us to the level of traditions.

Second, reading traditions can be grasped by considering that the timetable reading lesson is just one example of many similar situations distributed more widely in time and space. In many other classrooms, other people participated in similar activities both before and after the performance of this particular lesson, with pupils reading texts under the guidance of a teacher. Some aspects of the lesson are therefore more stable and recurrent from one situation to another, and existing on a wider scale of time and place, as situationtranscending practices. For example, the way in which the classroom is physically organised, with the pupils sitting at their desks and the teacher standing in front of her desk at the front of the classroom, can be recognised as typical for a classroom environment. Also the way in which the teacher has an undisputed right to speak, while the pupils do not, is common in any classroom. In relation to the documents involved, the use of a textbook is a 
typical feature in primary school throughout a substantial historical era. Furthermore, reading a document with semiotic signs, such as a timetable, is an activity that involves the collective, historical resource of language.

Thus, the introduction of double dialogicity into an analysis of reading makes it fruitful to distinguish between historical reading traditions and locally situated reading activities. However, this distinction must be understood as analytical. The reading lesson exhibits document work that is situated in a specific historical situation, at the same time as it is tied into wider historical circumstances. The dialogue between situations involving reading and historical reading traditions is continuously concurrent.

\subsection{Some Aspects of Double Dialogicity}

In addition to historicity, Frohmann (2004b) highlights three aspects or properties that are important to take into account in the pursuit of understanding documentary practices, namely their materiality, their institutional situatedness, and their socially disciplined characteristics. In our view, these properties can be regarded as analytically fruitful dimensions of the dialogical interplay between documentary practices such as reading traditions and document work such as reading activities.

Our view is that reading, as a type of document work, is situated in a material sense and that this material situatedness is intertwined with social, historical, and institutional practices (see Frohmann, 2004b). It involves semiotic mediation, which means the interpretation of signs that have been inscribed into/onto a physical artefact (Linell, 2009, p. 21; Säljö, 2005, p. 96ff). This interpretation of reading means that it is not regarded as an abstract and disembodied activity, but an activity that involves physical documents, physical manipulation of these documents, as well as the physical organisation of people reading (Chartier, 2006).

In the example of the reading lesson the material aspects of reading become apparent for example when the physical textbooks are handed out; when the teacher asks everyone to find a specific page in these textbooks; when one pupil reads aloud; when another pupil is told by the other pupils that they are reading too quietly; or when the teacher needs to put on her spectacles in order to read a particular piece of a text. It is through material instances like these that reading can be empirically studied. However, the emphasis on materiality should not only be seen as a practical necessity in the study of reading, but also as a theoretical statement about the material, historical, and social situatedness of all types of document work.

Through their materiality, documentary practices can be understood as situation-bound, as well as situation-transcending. Document work is necessarily physically situated in space and time, such as in the timetable reading lesson. But physical documents also play an important role for situation-transcending practices in human history. They function as external memory systems (Säljö, 2005, pp. 50ff) whose inscriptions (often, but not always) can be accessed and used long after they were recorded. Practices around and with documents may also continue from one situation to another, forming part of a tradition. The ways in which different types of documents are read often depend on the socialisation of reading activities in relation to certain reading traditions. This is apparent in educational institutions, where a large proportion of time is devoted to training pupils to approach certain types of 
inscriptions and documents in certain ways. Institutions, such as primary schools, provide certain traditions and regularities in terms of how specific types of documents are used. An important aspect of studying document work, such as reading, is to understand the institutional site of documentary practices and reading traditions.

The institutional framing of the train timetable lesson is important for how document work is carried out in this instance. For example, an outdated timetable would be of little use in many circumstances, but for the purposes of this reading activity, the old timetable is relevant. In this educational setting, the age of the document is of less importance than in a situation where the pupils are actually planning to catch a specific train. The use of the old timetable together with a textbook is a good example of how document work in an educational setting reflects the fact that the role of this institution is to prepare pupils for any number situations to come, rather than a specific instance. This mandate of the institution creates specific framings for the actual activities taking place in school settings. The institution is a contextual layer providing resources, motives, and routines that come into play when the timetables are made meaningful in specific, situated reading activities.

Other typical institutional features of the reading activity are, for example, that one person (the teacher) has the right to assign the others present (the pupils) to read aloud, as well as asking them questions that she already knows the answer to. This pattern is well-known in educational research and is called the Initiation-Response-Evaluation (IRE) sequence (Mehan, 1979). In this case, the pupils are also asked to construct similar IRE questions for their peers at the end of the lesson. Thus, the document work involved in the reading of the timetables is formed by the institutional setting and its routinised patterns of the organisation of reading. The institutional framing of this site shapes the reading activities taking place there, as well as the reading traditions formed through specific processes of institutional disciplining.

Closely linked to the institutional framing of reading are its disciplining aspects. Influenced by Foucault (1972; 1979) Frohmann (2004a) emphasises that documentary practices are socially disciplined: "documentary practices, like most others, require training, teaching, correction, and other disciplinary measures" (p. 397). Similarly, McKenzie and Davies (2010), with reference to Trace's study of primary school pupils' creation and use of documents (2007), highlight that document work "requires the situated understanding of how documents are and ought to be produced and used in a particular setting" (McKenzie and Davies, 2010, p. 789). This understanding is something that is learnt, in part through disciplinary processes. Hence, the teaching of reading always involves discipline in some sense.

From the perspective of dialogism, dominance, hegemony, and discipline exist both on the levels of situational activities and cultural traditions (see Linell 2009, pp. 212-217). In institutional settings, asymmetric dialogue is not uncommon, and is obvious in interactions between teachers and pupils in school. Linell (2009, p. 215) highlights that " $[w]$ ithin organizations of education, the practices of official evaluation, marking (grading) texts and achievements, have strong impact on behavior". This is important to take into account when analysing reading activities in educational settings. 
In the case of the train timetable reading lesson disciplinary aspects are quite clear on the situational level. The specific activity of the train timetable example involves the disciplining of pupils, such as classroom management and reprimanding by the teacher. An interesting aspect is that Swedish schools at the time were adjusting to a system where corporal punishment had been banned and other disciplinary methods needed to be developed (Qvarsebo, 2013; see also Dolatkhah and Lundh, 2014).

Disciplining efforts are also evident on the level of the reading practices of school in a more general sense, and in the very idea of schooling. Educational institutions, as well as library institutions, promote and sanction certain ways of reading, thereby excluding others. Furthermore, there is a political dimension to the interests these institutions are set to serve. The introduction of a nine-year comprehensive and compulsory school was new at the time of the train timetable example. The idea that all children, regardless of socioeconomic background and aptitudes, were expected to learn how to read and to learn specific ways of reading, is historically novel.

In the example of the train timetable, we can see how the pupils are trained to read in institutionally sanctioned ways. The inclusion of exercises in reading print timetables in the textbook shows that this type of reading was considered important and necessary at this time; the example illustrates the enactment of ideas of what documentary work all citizens should be able to participate in, in post-war Sweden. Hence, the idea of the disciplined reading should not only be understood in negative terms of punishment, but also in terms of support structures for specific types of productivity (see Frohmann, 2004a, p. 147). Furthermore, as Linell (2009, p. 216) highlights, the positions of different actors, such as the teacher and the pupils in the timetable lesson, are constantly negotiated at the level of situated interaction. Institutional disciplining shapes reading activities but it does not determine them.

\subsection{Reading as Meaning-Making}

A common view of reading is that it is about extracting the pre-existing meaning of the information in a document and then using or being affected by this information in some way. This is a different view to that of reading as a meaning-making activity. From a dialogistic perspective, Linell argues, meaning is seen as something produced in and through interaction, and not something that is revealed through information processing or individual behaviours (Linell, 2009, p. 221). Moreover, Frohmann (2004b, pp. 396) argues, again with the help of Wittgenstein, that the meaning - or the informativeness - of a document is not something inherent which is just there ready to be decoded. Rather, documents become informative through documentary practices and document work.

The train timetable lesson can illustrate this view of reading as meaning-making, as it shows (as mentioned above) how the consultation of an old train timetable, which is generally meaningless if you are planning to catch a train, can become meaningful in an educational situation. However, this view of reading activities as meaning-making activities does not suggest a totally relativistic view where a document could mean anything depending on the situation. But it does suggest that "there is no a priori reason to assume a unified role for specific document types" (Frohmann, 2004a, p. 115), nor is there any reason to assume that 
reading - even of a factual text such as a timetable - is about extracting the only meaning of a document.

Of course, the act of reading involves the decoding of already existing signs and, furthermore, social traditions and expectations invite certain interpretations of a text and make others undesirable or even impossible. Linell argues that utterances and artefacts have certain "affordances", possibilities to be interpreted as something "...given the presence of an appropriate, resonate interpreter" (Linell, 2009, p. 333). The meaning-making of a reading activity thus entails the interaction between semiotic signs, traditions and people in particular situations. An example of this is that the timetable in the reading lesson contains several specific signs besides the alphanumerical ones, and that the interpreters - the teacher and the pupils - need to follow a particular decoding practice in order to make sense of them in the way intended. This is highlighted by the teacher when she says "You have to understand the signs, what they mean". In a very concrete sense, this exemplifies how the meaning of a reading situation depends on interpretive practices and conventions. However, how practices and conventions shape meaning-making reading activities depends, as discussed above, on the situation in which the activities are situated. They function as resources for activities but not as determinants.

\section{Discussion and Concluding Remarks}

The train timetable lesson, in which a teacher is instructing her primary school class how to read a print timetable, was introduced above to exemplify how reading activities can be understood as document work in specific situations and at the same time as situationtranscending activities tied into documentary and reading practices. The aspects of reading presented above are meant to be understood as simultaneous and related to one another: The document work of reading is meaning-making because of its unavoidable situatedness in time, in traditions, in institutions, and in social and material places and spaces.

It is a document theory founded in dialogism that allows us to regard the reading activities during the lesson as situated document work and as part of documentary practices. Dialogism, with its emphasis on the interconnectedness between individuals and overarching structures through language, provides a theoretical basis and an epistemology to document theory and its focus on the materiality of documents. Dialogism has epistemological consequences in that the actual practice of studying meaning-making activities, such as reading, is regarded as a dialogical practice. The tools used for understanding empirical phenomena, such as data collection instruments, specialised languages, and genres of scholarly communication make the analysis a dialogical enterprise. Furthermore, the empirical phenomena - such as reading activities -are dialogic in themselves. Hence, the study of social activities and practices, such as reading activities and practices, involves creating understandings of situations in which people are creating understandings in and through their interactions. (Linell 2009, p. 29; see also Lundh, 2011, p. 27)

The theoretical framework outlined in this paper offers an alternative to monologist, general, prediction-aspiring, information-based theories and models of people's behaviours and practices prevalent in LIS. We contend that document work such as reading should be possible to study in its own right within LIS, without conceptualising it through the elusive 
concept of information (see Frohmann, 2004a, p. 83). Outside LIS, reading is an established object of study and theorising in disciplines such as educational science, sociology, history, psychology, linguistics, literature, and neuroscience. If reading can be studied as something other than an information activity or as information behaviour, what would be the rationale for studying it within LIS? Would there be anything unique in such an approach? These questions could render a few different answers.

First, one might argue, it is not fruitful to search for one single core theory and/or problem from which all LIS research can be derived. Rather, LIS can be considered as a cluster of related problems open for conceptualisation and analysis from different viewpoints. One such viewpoint, then, could be that in which an interest is taken in what people do with documents. This more pragmatic view, however, comes with the responsibility of looking for the possibilities of interplay and exchange between different problem areas and perspectives, within and outside of the LIS. LIS - as a discipline and not a number of separate subfields - will only occur in and through such exchanges.

Second, from a practical viewpoint, reading is, and has been for centuries, a central part of the activities of institutions such as libraries, schools, universities, and private enterprises. In many cases the concept of reading is probably well related to the experiences of users. When flicking through a newspaper, studying for an exam or opening an email with a meeting agenda attached, people do probably think about what they are doing as 'reading' rather than for example 'engaging in information seeking', 'practising information literacy' or 'using information'. In everyday life, in educational contexts, and in workplace settings, reading is as an integral part of people's activities. An objection may, however, be that this everyday understanding of reading as an activity does not provide a strong enough reason to take up the concept of reading as a theoretical and analytical concept, as everyday concepts do not necessarily have the theoretical depth needed for creating an analytical distance.

This leads us to the third response, which has to do with theory, as well as ontology and methodology. The framework presented in this paper could function as one fruitful approach to the study of reading in LIS. On an ontological and methodological level, the framework invites us to regard reading as a concrete and material activity that can be empirically studied. On the theoretical level, the framework invites us to regard reading as a social and societal phenomenon where the distinction and interplay between situations and traditions is a way of conceptualising the social. In other disciplines and fields, reading is often seen as on object of teaching and learning and is often studied from an evaluative perspective. The idea of reading as document work and part of documentary practices, rather than for example, as literacy or reading acquisition, makes it possible to study reading in educational and other settings and without necessarily evaluating people's reading skills or methods for the teaching of reading. Instead, the framework makes it possible to study what, for example, ways of teaching and valuing reading in a specific era and situation, might say about a particular society, rather than about specific individuals.

Finally, a focus on reading and other document work as conceptualised in this paper, might bridge the traditional dichotomy within LIS between reading research and information behaviour research. Whereas LIS reading research often ties the concept of reading to school, public and children's librarianship, fiction and activities such as leisure reading and 
reading promotion (e.g. Ross, 2009; Ross et al., 2006), information behaviour research often focuses on utilitarian activities within education, science and technology, and professional life. However, when reading is regarded as a type of document work which is intertwined with other aspects of document work such as the production, dissemination, and organisation of documents, the division between, on the one hand, reading for pleasure, and on the other hand, utilitarian information behaviour becomes less relevant. A dialogically based document theory offers theoretical tools that could be useful for the LIS study of a range of empirical phenomena, in many types of situations and traditions. The realisation of these possibilities, however, requires willingness to go beyond the entrenched idea of information as the core theoretical concept and empirical object of study of our discipline.

[ ${ }^{1}$ The lesson described is included in a current research project, Reading, traditions and negotiations: Reading activities in Swedish classrooms 1967-1969. A total of 223 lessons in the subject of Swedish is analysed within this project and the railway timetable lesson is one of 115 lessons which contains the teaching of reading (see Dolatkhah and Lundh, submitted). The lessons stem from a data set collected by a group of educational researchers at Gothenburg University in Sweden. The data collection was conducted during the academic years of 1967/1968 and 1968/1969 in 80 purposefully selected primary school classrooms in south-western Sweden within a research project that was called Didactic Process Analysis (see Bredänge et al., 1971). The main methods of data collection in the original project were video and sound recordings of several hundred lessons in grade six (which at this time was the last year of primary school). Each lesson was captured through a video recording where every fourth minute was recorded and a sound recording of the whole 40 minute lesson.] 


\section{Acknowledgments:}

The writing of this paper was made possible through the project Reading, traditions and negotiations: Reading activities in Swedish classrooms 1967-1969, funded by the Swedish Research Council 2013-2015, ref 2012-4140. The project is part of the Linnaeus Centre for Research on Learning, Interaction and Mediated Communication in Contemporary Society (LinCS) at the University of Gothenburg and the University of Borås, Sweden, funded by the Swedish Research Council, ref 349-2006-146.

An early version of this paper, "Dialogical documentary practices: analysing reading in Swedish primary school classrooms 1967-1969 " was presented at DOCAM 13, The Annual Meeting of the Document Academy, at the University of Troms $\varnothing$, Norway, 19-22 June 2013.

We would like to thank the DPA original researchers and participants, as well as Jonas Emanuelsson, Oskar Lindwall, Elin Johansson, Charlotte Sellberg and Erik Lundberg at Gothenburg University for all their efforts to make the data available to us; Niclas Hardman and Jan Buse at the University of Borås for their technical assistance; Rebecca Buse Landmér at the Swedish School of Library and Information Science (SSLIS) for her professional editing of the picture; Frances Hultgren at SSLIS, Christine Yates and Keith Hampson for their help with the English editing of the manuscript; and Helena Francke and Ola Pilerot (2011) at SSLIS for helpful guidance in the area of document theory.

\section{Biographical Details:}

Dr Anna Hampson Lundh is Senior Lecturer at the Swedish School of Library and Information Science and a Member of the Linnaeus Centre for Research on Learning, Interaction and Mediated Communication in Contemporary Society, at the University of Borås and the University of Gothenburg, Sweden. She is also Senior Research Fellow at the Department of Information Studies, Curtin University, Perth, Western Australia. Her research interests include children's reading and documentary practices, and accessible media.

Dr Mats Dolatkhah is Senior Lecturer at the Swedish School of Library of Information Science at the University of Borås, Sweden. In his research, Mats takes an interest in the history of reading as well as reading in the contemporary society. He is especially interested in children's reading practices during the 1900s, both within and outside formal education. 


\section{References}

Bates, M. J. (2010), "Information", in Bates, M.J. and Maack, M.N. (eds.), Encyclopedia of library and information sciences, (3. ed.), CRC Press, Boca Raton, FL, pp. 2347-2360.

Bredänge, G., Gustafsson, B., Hallin, G., Ingvarson, A., Odhagen T. and Stigebrandt, E. (1971), Didaktisk processanalys: presentation av syften, uppläggning, undersökningsgrupper och mätinstrument samt några beskrivande data [Didactic process analysis: presentation of purposes, design, groups, measurement instruments and some descriptive data]. Lärarhögskolan, Gothenburg.

Buckland, M. K. (1997), "What is a 'document'?", Journal of the American Society for Information Science, Vol. 48, No. 9, pp. 804-809.

Buckland, M.K. (2013), "Award of Merit acceptance speech", Bulletin of the American Society for Information Science and Technology, Vol. 39, No. 3, pp. 49-51.

Case, D.O. (2012), Looking for information: a survey of research on information seeking, needs, and behaviour, (3., [expanded] ed.), Emerald, Bingley.

Chartier, R. (2006), "Labourers and voyagers: from the text to the reader", in Finkelstein, D. and McCleery, A. (eds.), The book history reader, Routledge, London, pp. 87-98.

Dolatkhah, M. and Lundh A.H. (2014), "Reading, democracy and discipline: premises for reading activities in Swedish primary schools from 1967 to 1969", in Lauristin, M. and Vihalemm, P. (eds.), Reading in changing society, Tartu University Press, Tartu, pp. 144-157.

Dolatkhah, M. and Lundh A.H. (submitted), "Fragmentary flipping or immersive experience?: reading activities in Swedish compulsory school, 1967-1969".

Foucault, M. (1972), The archaeology of knowledge and the discourse on language, Pantheon Books, New York.

Foucault, M. (1979), Discipline and punish: the birth of the prison, Vintage, New York.

Frohmann, B.P. (2004a), Deflating information: from science studies to documentation, University of Toronto Press, Toronto.

Frohmann, B. (2004b), "Documentation redux: prolegomenon to (another) philosophy of information", Library Trends, Vol. 52, No. 3, pp. 387-407.

Frohmann, B. (2009), "Revisiting 'what is a document?'”, Journal of Documentation, Vol. 65, No. 2, pp. 291-303.

Furner, J. (2004), “Information studies without information”, Library Trends, Vol. 52, No. 3, pp. 427-446. 
Hartel, J. (2010). "Managing documents at home for serious leisure: a case study of the hobby of gourmet cooking", Journal of Documentation, Vol. 66, No. 6, pp. $847-874$.

Linell, P. (2009), Rethinking language, mind, and world dialogically: interactional and contextual theories of human sense-making, Information Age Publ., Charlotte, NC.

Lund, N.W. (2010), "Document, text and medium: concepts, theories and disciplines", Journal of Documentation, Vol. 66, No. 5, pp. 734 - 749.

Lund, N.W. and Skare, R. (2009), "Document theory", in Bates, M.J. and Maack, M.N. (eds.), Encyclopedia of library and information sciences, (3. ed.), CRC Press, Boca Raton, FL, pp.1632-1639.

Lundh, A. (2011), Doing research in primary school: information activities in project-based learning, Valfrid, Borås, available at: http://hdl.handle.net/2320/8610 (accessed 30 June 2015).

McKenzie, P.J. and Davies, E. (2010), “Documentary tools in everyday life: the wedding planner", Journal of Documentation, Vol. 66, No. 6, pp. 788 - 806.

Mehan, H. (1979). Learning lessons: social organization in the classroom, Harvard U.P, Cambridge, Mass.

Pawley, C. (2002), "Seeking 'significance': actual readers, specific reading communities", Book History, Vol. 5, pp. 143-160.

Pawley, C. (2006), "Retrieving readers: library experiences", Library Quarterly, Vol. 76, No. 4, pp. 379-387.

Pilerot, O. (2011), "On documentary practices", available at http://www.adm.hb.se/ opi/Pilerot paper on documentary practices.pdf (accessed 15 December 2014).

Qvarsebo, J. (2013), "Swedish progressive school politics and the disciplinary regime of the school, 1946-1962: a genealogical perspective", Paedagogica Historica, Vol. 49, No. 2, pp. 217-235.

Ross, C.S. (1999), "Finding without seeking: the information encounter in the context of reading for pleasure", Information Processing and Management, Vol. 35, No. 6, pp. 783-799.

Ross, C.S. (2009), "Reader on top: public libraries, pleasure reading and models of reading", Library Trends, Vol. 57, No. 4, pp. 632-656.

Ross, C.S., McKechnie, L. and Rothbauer, P. (2006), Reading matters: what the research reveals about reading, libraries, and community, Libraries Unlimited, Westport, Conn. 
Rothbauer, P. (2004), “'People aren't afraid anymore, but it's hard to find books': reading practices that inform the personal and social identities of self-identified lesbian and queer young women", The Canadian Journal of Information and Library Science, Vol. 28, No. 3, pp. 53-74.

Säljö, R. (2005), Lärande och kulturella redskap: om lärprocesser och det kollektiva minnet. [Learning and cultural tools: on learning processes and the collective memory], Norstedts akademiska förlag, Stockholm.

Trace, C.B. (2007), "Information creation and the notion of membership", Journal of Documentation, Vol. 63, No. 1, pp. 142-164. 